\title{
ЗАСТОСУВАННЯ ПРАКТИКИ ЄВРОПЕЙСЬКОГО СУДУ З ПРАВ ЛЮДИНИ У ВІТЧИЗНЯНОМУ КРИМІНАЛЬНОМУ ПРОВАДЖЕННІ
}

Пчеліна О.В.

Наголошено на необхідності застосовувати практику Європейського суду з прав людини у вітчизняному кримінальному провадженні з метою забезпечення приведення національного кримінального процесуального законодавства у відповідність до європейських стандартів прав людини. Акцентовано увагу на комплексному характері діяльності із застосування практики Європейського суду з прав людини. Визначено та охарактеризовано основні напрями застосування практики Європейського суду з прав людини у вітчизняному кримінальному провадженні.

Ключові слова: Європейський суд з прав людини, практика ЄСПЛ, кримінальне провадження, європейські стандарти прав людини.

Отмечена необходимость применять практику Европейского суда по правам человека в отечественном уголовном производстве с целью обеспечения приведения начионального уголовного процессуального законодательства в соответствие с европейскими стандартами по правам человека. Акцентировано внимание на комплексном характере деятельности по применению практики Европейского суда по правам человека. Определены и охарактеризованы основные направления применения практики Европейского суда по правам человека в отечественном уголовном производстве.

Ключевые слова: Европейский суд по правам человека, практика ЕСПЧ, уголовное производство, европейские стандарты прав человека.

Pchelina O. V. Application of the case law of the European Court of Human Rights in domestic criminal proceedings

It has been noted that, by ratifying the Convention for the Protection of Human Rights and Fundamental Freedoms, Ukraine has undertaken to implement the decisions of the European Court of Human Rights in cases against Ukraine; elimination of the reasons for its violation of the Convention and its protocols; to introduce European human rights standards into Ukrainian justice and administrative practice; to create preconditions for reducing the number of applications to the European Court of Human Rights against Ukraine. Of particular note are the use of European Court of Human Rights judgments in law enforcement and the fight against crime. In this context, the need to apply the case law of the European Court of Human Rights in domestic criminal proceedings in order to ensure the harmonization of national criminal procedure legislation with European human rights standards has been emphasized. Emphasis has been placed on the complex nature of the application of the case law of the European Court of Human Rights. The main directions of application of the case law of the European Court of Human Rights in domestic criminal proceedings have been identified and characterized. The case law of the European Court of Human Rights has been found to be used in criminal proceedings by both the defense and the prosecution and the court. It has been noted that in fact not all areas of application of the case law

(с) Пчеліна О. В., 2020 of the European Court of Human Rights in domestic criminal proceedings are fully implemented, which leads to frequent violations of human rights and fundamental freedoms in criminal proceedings at the stages of detection of criminal offenses, their pre-trial investigation and court proceedings, including the execution of court decisions. The application of the case law of the European Court of Human Rights in criminal proceedings is carried out mainly by implementing the decisions of the European Court of Human Rights in the application of individual measures, as well as making certain changes to national criminal procedural law and conducting scientific activities to apply international and European standards of human rights, including the case law of the European Court of Human Rights.

Key words: European Court of Human Rights, case law of the European Court of Human Rights, criminal proceedings, European standards of human rights.

Постановка проблеми та її актуальність. Ратифікуючи Конвенцію про захист прав людини і основоположних свобод (далі - Конвенція) [1; 2], Україна взяла на себе обов'язок з виконання рішень Європейського суду з прав людини (далі - ЄСПЛ) у справах проти України: усунення причин порушення нею Конвенції і протоколів до неї; впровадження в українське судочинство та адміністративну практику європейських стандартів прав людини; створення передумов для зменшення числа заяв до ЄСПЛ проти України [3]. Особливу увагу заслуговують питання використання рішень ЄСПЛ у діяльності правоохоронних органів і суду, пов'язані з боротьбою зі злочинністю, оскільки, як указує М.В. Гребенюк, одним із ключових і важливих напрямів удосконалення сучасної правоохоронної діяльності $є$ адаптація та приведення у відповідність із кращими практиками європейського досвіду як завдань кримінального провадження, так і завдань діяльності правоохоронних органів і суду. Це дозволить впровадити європейські стандарти прав людини при здійсненні правосуддя в Україні, що у свою чергу безпосередньо вплине на розвиток українського законодавства та правозастосовної практики [4, с. 48, 51]. Тобто практика ЄСПЛ має стати фактором розвитку національного законодавства, зокрема кримінального процесуального, приведення його у відповідність з європейськими стандартами прав людини [5, с. 56]. У контексті зазначеного вважаємо актуальним питання про застосування практики ЄСПЛ у вітчизняному кримінальному провадженні.

Аналіз останніх досліджень і публікацій. Питання використання європейських стандартів прав людини у вітчизняному законодавстві та судочинстві досліджували Р.В. Бараннік, М.В. Гребенюк, Л.Л. Грица-

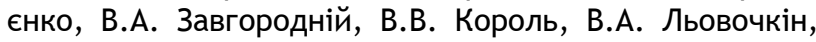
А.А. Марченко, О.П. Кучинська, П.В. Пушкар, Т.І. Фулей, В.Д. Юрчишин та інші вчені. У напрацюваннях науков- 
ців сформульовані принципово важливі положення про засади, значення та заходи застосування практики ЄСПЛ у діяльності правоохоронних і судових органів України. Особлива увага приділяється питанням застосування судами України Конвенції та практики ЄСПЛ, а також використання європейських стандартів прав людини в законотворчій діяльності нашої держави. При цьому особливості застосування практики ЄСПЛ у вітчизняному кримінальному провадженні, пов'язані 3 формуванням окремих криміналістичних методик, тактико-технічних рекомендацій щодо проведення окремих слідчих (розшукових), негласних слідчих (розшукових) та інших процесуальних дій, висвітлюються в науковій літературі фрагментарно.

Тому метою статті $\epsilon$ визначення i характеристика основних напрямів застосування практики ЄСПЛ у вітчизняному кримінальному провадженні.

Виклад основного матеріалу. Впровадження стандартів забезпечення прав людини, визнаних європейським та загальносвітовим співтовариством, у процесі провадження кримінальної процесуальної діяльності $\epsilon$ об'єктивною необхідністю на шляху прагнення України виступати рівноправним учасником у міжнародних відносинах з Радою Європи та Європейським Союзом. Розпочатий у нашій державі процес приведення національного законодавства у відповідність із загальновизнаними стандартами та нормами окремими дослідниками називається по-різному: адаптація, уніфікація, апроксимація, гармонізація, наближення, трансформація тощо. Буквальне розуміння тих процесів, які відбуваються у контексті цього синонімічного ряду, полягає у пристосуванні чинних внутрішньодержавних правових норм, інститутів та механізмів до міжнародних зобов'язань України, а також чинних загальновизнаних стандартів у тій чи іншій сфері. Такий процес пристосування відбувається, зокрема, шляхом включення загальновизнаних міжнародних стандартів та принципів кримінального провадження в галузі прав людини у вітчизняне кримінальне процесуальне законодавство [6, с. 42-43]. Тому з огляду на необхідність приведення українського права у відповідність до норм і принципів міжнародного права важливим уявляється вивчення європейського правового досвіду та європейської правової доктрини [7].

Так, чимала роль у процесах адаптації вітчизняного законодавства, зокрема кримінального процесуального, до міжнародних стандартів відводиться застосуванню практики ЄСПЛ, адже, як зазначає Т.І. Слуцька, за правилами ч. 4 ст. 9 Кримінального процесуального кодексу України (далі - КПК України) у разі, якщо його норми суперечать міжнародному договору, згода на обов'язковість якого надана Верховною Радою України, у кримінальному провадженні застосовуються положення відповідного міжнародного договору України. Крім цього, за змістом ч. 5 ст. 9 КПК Україні кримінальне процесуальне законодавство України застосовується з урахуванням практики ЄСПЛ [8; 9].

ЄСПЛ, як вірно вказує В.А. Завгородній, $є$ міжнародною судовою інстанцією, яка здійснює свою діяльність 3 метою забезпечення верховенства права, захисту прав і свобод людини шляхом розгляду індивідуальних чи колективних скарг від громадян держав-учасниць Конвенції про захист прав та основоположних свобод i встановлення справедливих компенсацій, рішення якої мають прецедентний характер. При цьому вчений наголошує, що рішення ЄСПЛ мають обов'язковий для виконання характер не лише для учасників конкретного процесу, а й для всіх держав, які ратифікували Конвенцію [10, с. 57].

Україна, на превеликий жаль, входить до трійки лідерів-скаржників до суду, що свідчить про системність порушень норм Конвенції. У зв'язку з чим, як слушно підмічають Д.О. Лук'яненко, І.М. Білодід, ґрунтовне та повне вивчення рішень ЄСПЛ $\epsilon$ необхідною, навіть обов'язковою частиною правильного застосування національного законодавства та забезпечення неухильного виконання норм Конвенції. При цьому сторона обвинувачення повинна бути обізнаною з практикою ЄСПЛ для запобігання порушень прав учасників процесу та для відстоювання своєї позиції [11, с. 117, 119].

Разом із тим заслуговує на увагу і твердження Ула Кварнстрома з приводу застосування практики ЄСПЛ, в якому робиться акцент на тому, що питання про використання практики ЄСПЛ $€$ комплексним і складним. Його вирішення передусім пов'язане з підвищенням правової свідомості. Зокрема, експерт Консультативної місії Європейського Союзу, ділячись із досвідом Швеції в імплементації практики ЄСПЛ в національну правову систему, відзначає, що сторона захисту у Швеції зазвичай використовує практику ЄСПЛ. Тому можна стверджувати, що до певної міри кожен захисник у Швеції $\epsilon$ експертом з питань Європейського суду з прав людини. Але вони навчені, натреновані бути експертами у своїх вузьких сферах. Наприклад, вони можуть звернутися до судді щодо визнання людини невинуватою у зв'язку з тим, що допити відбувалися неналежним чином. Для сторони обвинувачення (прокурорів) у Швеції розроблено методичні рекомендації щодо того, яким чином виконувати свої обов'язки відповідно до Конвенції з прав людини. Природа цих рекомендацій $€$ дуже практичною. Тому якщо, наприклад, прокуророві необхідно виступити перед $3 \mathrm{MI}$, він із рекомендацій дізнається, що він може говорити, а що ні, i як зробити це таким чином, щоб уникнути звинувачення в тиску [12].

3 вищенаведеного помітно, що практика ЄСПЛ використовується у кримінальному провадженні як стороною захисту, так і стороною обвинувачення та судом. Це означає, що повинні розроблятися відповідні рекомендації стосовно питань використання ЄСПЛ з урахуванням специфіки діяльності як захисників, так і правоохоронних органів і суду. При цьому варто запозичувати досвід зарубіжних країн з ефективного забезпечення застосування практики ЄСПЛ під час здійснення правосуддя.

Зокрема, у Франції порядок виконання рішень ЄСПЛ слабо формалізований. Названа держава прагне виконувати рішення ЄСПЛ не шляхом зміни законів, а шляхом удосконалення правозастосовної практики по конкретних категоріях справ, а також через використання принципів і стандартів, що визначені в Конвенції та рішеннях ЄСПЛ (наприклад, принцип пропорційності обмеження прав і свобод людини, принцип якості закону та інші). У результаті основну роль щодо виконання рішень ЄСПЛ у частині заходів загального характеру відіграють судові органи держави, органи прокуратури та інші суб'єкти правозастосування [10, с. 59; 13, с. 85]. 
щодо Федеративної Республіки Німеччини, то вказана держава вважає за необхідне виконувати не тільки рішення ЄСПЛ, що винесені стосовно неї, а також вважає за необхідне інтегрувати у свою правову систему рішення по інших країнах. У Німеччині процедури виконання рішень ЄСПЛ у цілому формалізовані законодавчими і підзаконними актами, що визначають компетенцію і порядок роботи різних органів влади. Зокрема, заходи загального характеру полягають у тлумаченні рішень ЄСПЛ і застосуванні національних законів, зважаючи на них; розробці законопроектів і адміністративних заходів, які необхідні для виконання рішень ЄСПЛ; прийнятті відповідного закону [10, с. 60-61; 14, с. 112]. У Чеській Республіці реалізується різними органами влади виконання заходів загального характеру. Представник держави в ЄСПЛ відповідає за розробку рекомендацій про необхідні заходи загального характеру. Як правило, представник залучає до розробки рекомендацій різні органи влади і громадські організації (профспілки, асоціації юристів тощо). Окрім того, в Чехії створено механізм, направлений на приведення законів та правозастосовної практики в країні у відповідність зі стандартами ЄСПЛ [10, с. 59; 15, с. 234].

Проаналізувавши вищенаведені положення, можна дійти висновку, що в країнах Європи застосування практики ЄСПЛ відбувається шляхом застосування заходів індивідуального та загального характеру. При цьому з числа заходів загального характеру найбільшого розповсюдження отримали прийняття відповідних законів згідно з практикою ЄСПЛ, тлумачення рішень ЄСПЛ і розроблення відповідних рекомендацій для судових, правоохоронних органів і правозахисних організацій.

В Україні виконання рішень ЄСПЛ також відбувається шляхом застосування заходів як індивідуального, так і загального характеру. Адже, як відзначає T.I. Фулей, якщо ЄСПЛ визнає факт порушення прав заявника з боку держави-відповідача, така держава зобов'язана не тільки вжити заходів індивідуального характеру (наприклад, виплатити справедливу сатисфакцію чи здійснити перегляд справи в судовому порядку), але також у багатьох випадках вжити певних заходів загального характеру [16, с. 7]. Зокрема, останніми $\epsilon$ заходи, спрямовані на усунення зазначеної в рішенні ЄСПЛ системної проблеми та іï першопричини, а саме: внесення змін до чинного законодавства та практики його застосування; внесення змін до адміністративної практики; забезпечення юридичної експертизи законопроектів; забезпечення професійної підготовки з питань вивчення Конвенції та практики ЄСПЛ прокурорів, адвокатів, працівників правоохоронних органів, працівників імміграційних служб, інших категорій працівників, професійна діяльність яких пов'язана із правозастосуванням, а також із триманням людей в умовах позбавлення свободи; інші заходи, які визначаються - за умови нагляду з боку Комітету міністрів Ради Європи - державою-відповідачем відповідно до рішення ЄСПЛ з метою забезпечення усунення недоліків системного характеру, припинення спричинених цими недоліками порушень Конвенції та забезпечення максимального відшкодування наслідків цих порушень [3].

Якщо вести мову про застосування практики ЄСПЛ у вітчизняному кримінальному провадженні, то вважаємо, що така діяльність повинна здійснюватися комплексно, тобто водночас за такими основними напрямами:

1) правове просвітництво населення, яке полягає в роз'ясненні громадянам та іншим жителям України про їхні права, механізми їх захисту, в тому числі за допомогою звернення до ЄСПЛ (проведення правових заходів, пізнавальних передач на радіо, телебаченні, онлайн-ресурсах, розповсюдження постів за допомогою соціальних мереж і т. п.);

2) підвищення стандартів i якості правової підготовки суддів, працівників правоохоронних органів та інших юристів-правознавців, у ході якої вивчається практика ЄСПЛ, способи їі застосування, а також отримуються навики із ії застосування у своїй професійній діяльності з метою недопущення порушення прав і свобод людини;

3) офіційне тлумачення рішень ЄСПЛ, положень Конвенції та кримінального процесуального законодавства з метою вироблення єдиної правозастосовної практики;

4) забезпечення здійснення експертизи проектів нормативно-правових актів щодо їх відповідності Конвенції та практиці ЄСПЛ з метою приведення національного законодавства, зокрема кримінального процесуального, у відповідність до міжнародних та європейських стандартів прав людини [17];

5) розроблення методичних рекомендацій стосовно застосування практики ЄСПЛ у діяльності суду, правоохоронних органів, а також суб'єктів, які надають правову допомогу;

6) урахування практики ЄСПЛ під час формування окремих криміналістичних методик, а також рекомендацій із приводу тактики проведення та техніко-криміналістичного забезпечення окремих слідчих (розшукових), негласних слідчих (розшукових) та інших процесуальних дій.

Проте фактично не всі названі вище напрями застосування практики ЄСПЛ у вітчизняному кримінальному провадженні реалізуються в повному обсязі, що призводить до частого порушення прав і основних свобод людини в кримінальній процесуальній діяльності як на стадіях виявлення кримінальних правопорушень, їх досудового розслідування, так і судового провадження, в тому числі виконання судових рішень. Застосування практики ЄСПЛ у кримінальному провадженні здійснюється в основному шляхом виконання рішень ЄСПЛ під час застосування заходів індивідуального характеру, а також внесення певних змін до національного кримінального процесуального законодавства та проведення наукових заходів, приурочених до застосування міжнародних і європейських стандартів прав людини, в тому числі практики ЄСПЛ.

Зокрема, одним із найважливіших кроків на шляху приведення вітчизняного кримінального провадження у відповідність до міжнародних стандартів прав людини вважається прийняття в 2012 році нового КПК України [9]. Із цього приводу П.В. Пушкар, аналізуючи вплив Конвенції про захист прав людини і основоположних свобод та практики Європейського суду з прав людини на формування завдань сучасного кримінального судочинства України, наголошує, що завдання кримінального провадження відповідно до КПК України 1960 року фактично відображають ідеї інквізиційного процесу постімперського та пострадянського періодів, де в основі кримінально-процесуальної 
діяльності були ідеї насамперед встановлення наявності або відсутності вини особи (скоріше, в напрямі встановлення вини особи, оскільки сама кримінально-процесуальна діяльність мала значні ознаки «надмірного обвинувального спрямування») за будь-яких умов, нехтуючи принципом презумпції невинуватості, іноді із застосуванням у тому числі незаконних способів та методів розслідування i, відповідно, процедур судового розгляду, не заснованих на принципах змагальності та рівності сторін судового провадження, де, зокрема, суд діяв фактично як сторона обвинувачення (наприклад, практика проголошення обвинувального висновку суддею). Найважливіше, визнання особою вини та забезпечення завдань розслідування з точки зору встановлення доволі абстрактного правового орієнтиру - встановлення об'єктивної істини були фактично основними завданнями кримінального провадження. Принцип «законності» розглядався в цьому контексті з формально-позитивіської точки зору - дотримання формального писаного закону або навіть процесуальних інструкцій, настанов ієрархічно вищих партійних, судових або правоохоронних органів чи нормативних актів, що регулювали процесуальні дії слідчого, прокурора та навіть судді. Із прийняттям нового КПК України 2012 року ст. 2 КПК України в поєднанні з вимогами ст. 8 КПК України передбачає застосування положень кримінального процесуального закону, виходячи з дотримання принципу верховенства права, відповідно до тлумачення цього принципу через призму практики ЄСПЛ. У такий спосіб, як підкреслює вчений, відбулася зміна моделі завдань кримінального провадження з моделі «контролю за злочинністю» (crime control) та розвитку моделі кримінального правосуддя (в широкому сенсі) в напрямі не тільки due process model (модель «належного процесу»), а і певного розвитку цієї моделі кримінального правосуддя у напрямі моделі «захисту прав людини», через призму положень кримінального процесуального закону [18, с. 146-147].

Висновки. Отже, в Україні як правовій державі людина, іï права й основоположні свободи повинні бути пріоритетною цінністю. Відповідно, в усіх сферах суспільного буття будь-яка діяльність завжди повинна реалізуватися згідно з міжнародними стандартами прав людини. 3 цією метою Україна виконує рішення та застосовує практику ЄСПЛ. При цьому діяльність із застосування практики ЄСПЛ у вітчизняному кримінальному провадженні $\epsilon$ багатосторонньою та складною, оскільки задля забезпечення іiі ефективності вона повинна реалізуватися комплексно, водночас за всіма напрямками.

\section{Література}

1. Конвенція про захист прав людини і основоположних свобод : конвенція Рада Європи від 04.11.1950 р. Офіційний вісник України. 1998. №13, № 32 від 23.08.2006. Стор. 270.

2. Про ратифікацію Конвенції про захист прав людини і основоположних свобод 1950 року, Першого протоколу та протоколів № 2, 4, 7 та 11 до Конвенції: закон України від 17.07.1997 р. № 475/97-ВР. Відомості Верховної Ради України. 1997. № 40. Ст. 263.

3. Про виконання рішень та застосування практики Європейського суду з прав людини : Закон України від 23.02.2006 р. № 3477-IV. Відомості Верховної Ради України. 2006. № 30. Ст. 260.
4. Гребенюк М.В. Аналіз деяких рішень Європейського суду з прав людини щодо проблемних питань боротьби зі злочинністю. Практика Європейського суду з прав людини в діяльності органів прокуратури і суду: виклики та перспективи : матеріали I Міжнародної науково-практичної конференції (13 червня 2018 року). Київ : Національна академія прокуратури України, 2018. С. 48-52.

5. Грицаєнко Л.Л. Значення заходів загального характеру у виконанні рішень Європейського суду з прав людини. Практика Європейського суду з прав людини в діяльності органів прокуратури і суду: виклики та перспективи : матеріали I Міжнародної науково-практичної конференції (13 червня 2018 року). Київ : Національна академія прокуратури України, 2018. С. 53-56.

6. Кучинська О.П., Фулей Т.І., Бараннік Р.В. Принципи кримінального провадження у світлі практики Європейського суду з прав людини : монографія. Ніжин : ТОВ «Видавництво «Аспект-Поліграф», 2013. 228 с.

7. Марченко А.А. Особливості застосування практики Європейського суду з прав людини. Шостий апеляційний адміністративний суд. URL: https://6aas.gov.ua/ua/ proekty/articles/m/2213-osoblivosti-zastosuvannya-praktikievropejskogo-sudu-z-prav-lyudini.html (дата звернення: 02.06.2020).

8. Слуцька Т.І. 250 правових позицій ЄСПЛ у кримінальному провадженні: оновлена, систематизована добірка. Юридичний портал Протокол. URL: https://protocol.ua/ua/250_pravovih_pozitsiy_espl_u_ kriminalnomu_provadgenni_onovlena_sistematizovana_dobirka/ (дата звернення: 03.06.2020).

9. Кримінальний процесуальний кодекс України : Закон України від 13.04.2012 р. № 4651-VI. Відомості Верховної Ради України. 2013. № 9-10, № 11-12, № 13. Стор. 474. Стаття 88.

10. Завгородній В.А. Зарубіжний досвід виконання рішень Європейського суду з прав людини (на прикладі деяких країн Європейського Союзу). Науковий вісник Дніпропетровського державного університету внутрішніх справ. 2013. № 1. С. 57-64.

11. Лук'яненко Д.О., Білодід І.М. Застосування практики Європейського суду з прав людини в діяльності органів прокуратури. Практика Європейського суду з прав людини в діяльності органів прокуратури і суду: виклики та перспективи : матеріали I Міжнародної науково-практичної конференції (13 червня 2018 року). Київ : Національна академія прокуратури України, 2018. С. 117-119.

12. Про досвід Швеції в імплементації практики ЄСПЛ в національну правову систему. Дзеркало суддів. URL: http://suddya.com.ua/news/pro-dosvid-svecii-vimplementacii-praktiki-espl-v-nacionalnu-pravovu-sistemu (дата звернення: 02.06.2020).

13. Коротеев К. Исполнение решений Европейского Суда по правам человека во Франции. Сравнительное конституционное обозрение. 2009. № 1 (68). С. 83-97.

14. Топорнин Б.Н. Европейские сообщества: право и институты. Динамика развития. Москва : Изд-во ИГиП РАН, 1992. 183 с.

15. Балик С. Опыт Конституционного суда Чешской Республики по приведению в исполнение решений Европейского Суда по правам человека. Имплементация решений Европейского Суда по правам человека в практике конституционных судов стран Европы : сб. докладов. Москва, 2006. С. 232-237.

16. Фулей Т.І. Застосування практики Європейського суду з прав людини при здійсненні правосуддя : науково-методичний посібник для суддів. 2-ге вид., випр., допов. Київ, 2015. 208 с.

17. Про здійснення експертизи проектів законів та проектів актів Кабінету Міністрів України, а також нор- 
мативно-правових актів, на які поширюється вимога державної реєстрації, щодо відповідності положенням Конвенції про захист прав людини і основоположних свобод та практиці Європейського суду з прав людини : Наказ Міністерства юстиції України від 20.08.2008 р. № 1219/7. Верховна Рада України. Законодавство України. URL: https: / /zakon.rada.gov.ua/laws/show/v1219323-08\#Text (дата звернення: 14.06.2020).

18. Пушкар П.В. Вплив Конвенції про захист прав людини і основоположних свобод та практики Європейського суду з прав людини на формування завдань сучасного кримінального судочинства України. Практика Європейського суду з прав людини в діяльності органів прокуратури і суду: виклики та перспективи : матеріали I Міжнародної науково-практичної конференції (13 червня 2018 року). Київ : Національна академія прокуратури України, 2018. С. 145-147.
Пчеліна О. В., доктор юридичних наук, доцент, доцент кафедри кримінального процесу та організації досудового слідства Харківського національного університету внутрішніх справ 